\title{
Analisis Kualitas Air Kali Ancar dengan Menggunakan Bioindikator Makroinvertebrata
}

Khairuddin, Muhammad Yamin dan Abdul Syukur

Dosen Program Studi Pendidikan Biologi FKIP UNRAM

\begin{abstract}
Abstrak
Air merupakan kebutuhan dasar manusia yang sedanag mengalami proses penurunan kualitas. Salah satu sumber daya air yang yang sangat penting adalah sungai. Sungai telah dimanfaatkan sebagai sumber air minum, mandi dan mencuci. Selain itu dimanfaatkan untuk kegiatan budidaya perikanan dan rekreasi. Sungai Kali Ancar adalah sungai yang sangat penting bagi masyarakat Kota Mataram. Berkaitan dengan kualitas air Kali Ancar telah dilakukan penelitian untuk menilai kualitas air dari aspek mutu air dengan indikator makroinvertebrata. Tujuan penelitian ini adalah menentukan tingkat kualitas air Kali Ancar Kota Mataram. Metode penelitian adalah adalah survey dan laboratorium. Analisi data spesies makroinvertebrata diidentifikasi dan dihitung untuk penentuan nilai indeknya. Kualitas air ditentukan oleh nilai indek LincolnPenelitian ini sangat penting bagi penentuan kualitas air dengan menggunakan indikator biologi atau Bioindikator. Luaran Penelitian berupa informasi atau data tentang kualitas air di sungai / kali Ancar berupa tingkat pencemaran.. Kesimpulan penelitian adalah kualitas air di kali Ancar tergolong kualitas rendah
\end{abstract}

Kata Kunci : Kualitas Air, Bioindikator, Makroinvertebrata 


\section{Pendahuluan}

Jumlah manusia meningkatn akan menekan sumberdaya termasuk sumberdaya air seperti air sungai. Sungai merupakan sumberdaya yang dapat dimanfaatkan untuk berbagai keperluan manusia termasuk untuk transportasi dan pariwisata termasuk kali Ancar yang ada di Kota Mataram. Semakin intensifnya transportasi akan semakin intensif gangguan terhadap flora dan fauna di sungai termasuk makroinvertebrata (Sukarsono, 2009; Maryono, 2007). Kualitas air sangat penting bagi manusia, karena setiap peruntukan air memerlukan persyaratan tersendiri baik untuk air mandi, bahan baku air minum ataupun untuk air perikanan. Kualitas air berhubungan dengan program kali bersih dari pemerintah kota Mataram saat ini. Air dapat dengan mudah tercemari oleh berbagai logam berat seperti timbal $(\mathrm{Pb})$, Tembaga $(\mathrm{Cu})$, dan merkuri (Hg) (Widowati, dkk, 2008; Bakrie, 2000).

Pencemaran merupakan hal senantiasa dihadapi manusia saat ini terutama pencemaran air. Pencemaran air dapat berasal dari sampah, limbah cair serta bahan pencemar lain seperti dari pupuk, pestisida, penggunaan detergen sebagai bahan pembersih, penggunaan bahan pembungkus yang menghasilkan banyak limbah dan sebagainya.

Hewan yang hidup di perairan sungai seperti makroinvertebrata dapat menjadi indikator dalam penentuan kualitas air di sungai atau kali tersebut seperti yang ada di Kota Mataram. Manusia sedapat mungkin memelihara dan menjaga keberadaan lingkungan hidup di sekitar tempat tinggalnya. Lingkungan atau lingkungan hidup adalah kesatuan ruang dengan semua benda, daya, keadaan, dan makhluk hidup, termasuk manusia dan perilakunya yang mempengaruhi kelangsungan perikehidupan dan kesejahteraan manusia serta makhluk hidup lain (Anonim,2000; Hadi. 2000, Soemantojo, 2004).

Air yang berkualitas baik adalah merupakan kebutuhan dasar manusia demikan juga dengan udara yang mengandung oksigen di dalamnya. Keberadaan air tidak saja ditentukan oleh jumlah tetapi juga mutu atau kualitasnya. Dalam kehidupan sehari-hari air yang berkualitas baik sangat menentukan kualitas kehidupan baik untuk manusia maupun makhluk hidup lainnya. makroinvertebrata dapat dijadikan indikator dalam menentukan kulaitas air (Tanjung, 2003; Soedradjat, 1999). Kualitas air dapat ditentukan dengan 
berbagai parameter seperti parameter fisika, kimia dan biologi. Penentuan kualitas air sungai secara kimia dan fisika memerlukan waktu lama dan biaya yang besar, maka penggunaan parameter biologi dengan menggunakan makroinvertebrata menjadi penting untuk dilakukan, termasuk dalam menentukan kualitas air di kali Ancar yang meliwati Kota Mataram

Sebagai bahan pembanding pada sungai jangkok di kota Mataram telah mengalami pencemaran. Hal ini diperkuat ole data pemantauan kualitas air yang dilakukan BLHP NTB pada 2010 di Sungai Jangkok yang merupakan sungai terbesar di Kota Mataram, kandungan "e-coli" mencapai 240.000 MPN (most probable number) per 100 mililiter atau jauh di atas standar baku mutu air kelas II sebesar 1.000 MPN/100 ml. Penelitian dilakukan termasuk di wilayah Kota Mataram yaitu dua wilayah tengah sungai dan dua wilayah hilir sungai jangkok di Kota Mataram (http://sumbawabaratnews.com, 2014). Terdapat kriteria organisme yang dapat digunakan sebagai indikator biologi dengan memperhatikan faktor : 1 . organisme harus sensitif terhadap material beracun dan perubahan linkungan, 2. penyebanya luas dan mudah didapat dalam jumlah yang banyak, 3. mempunyai arti ekonomi, rekreasi dan kepentingan ekologi baik secara daerah maupun nasional, 4. mudah dipelihara dalam laboratorium, mempunyai kondisi yang baik, bebas dari penyakit dan parasit dan 6. sesuai untuk kepentingan uji hayati (Mason, 1991; Jeffrey, dan Maden, 1994; Loeb, dan Spacie, 1994).

Kualitas air dapat ditentukan dengan berbagai parameter seperti parameter fisika, kimia dan biologi. Mengingat bahwa penentuan kualitas secara kimia dan fisika memerlukan waktu dan biaya yang besar, maka dikembangkanlah parameter biologi (Bioindikator). Tujuan dari penelitian ini yaitu ingin mengetahui tingkat kualitas air yang ada di kali ancar kota Mataram Luaran penelitian berupa informasi atau data tentang kualitas air di sungai / kali Ancar berupa tingkat pencemaran dan kuaitas air yang dapat digunakan untuk bahan referensi perkuliahan pada mata kuliah Pengetahuan Lingkungan.

Penggunaan bioindikator / indikator spesies tidak hanya terbatas pada ekosistem perairan, tetapi juga pada ekosistem darat. Soedradjat (1999), mengatakan bahwa indikator pencemaran udara dapat menggunakan tumbuhan sebagai bioindikator. Selain itu Linchenes dapat juga dijadikan bioindikator. Untuk mengetahui 
kualitas lingkungan seperti misalnya air, ada baiknya pengukuran terhadap parameter secara fisik, kimia dan biologi dilakukan, termasuk aspek mikrobiologi (Bakteri, bakteri patogen seperti vibrio cholera, algae (kandungan klorofil, spesies), virus dan protozoa (termasuk protozoa yang patogen). Aspek fisik yang umum diukur adalah bahan organik terlarut, turbiditas, warna, alkalinitas, rasa, dan bau ( Schippers, 1988).

Ketersediaan lingkungan yang sehat seperti sumber-sumber air tawar misalnya, adalah sangat penting untuk kelangsungan kehiduopan manusia di seantero dunia. Namun demikian, tekanan kebutuhan dan perlakuan manusia terhadap air menyebabkan kualitas air terus menurun (Loeb dan Spacie, 1994). Walaupun kehatihatian dari penggunaan air yang tersedia dan keberadaan air yang tak terpolusi masih tersebar, metode untuk mengevaluasi dari ekosistem aquatik untuk bendungan atau badan air lain seperti danau, sungai dan kolam masih kurang begitu berkembang untuk mengidentifikasi secara akurat kualitas dan perlindungan bagi kesehatan.

Kesehatan dari sistem perairan akan menurun ketika kemampuan untuk asimilasi diri untuk menyerap suatu keadaan stress oleh organisme meningkat. Walaupun perubahan satu ekosistem dalam bentuk perbaikan sendiri secara alami terkadang terjadi. Altivitas manusia sering menekan ekosistem (Freeman, 1989). Kalau organisme dari suatu ekosistrem mengalami stress, ketahanan dari suatu dampak perubahan dalam ekosistem akan memiliki gangguan. Katahanan tergantung dari perubahan alami sewaktu-waktu dari keadaan stress, walaupun sebagian organisma mungkin akan mampu bertahan dan mengembalikan keadaan seperti keadaan semula (Jeffrey dan Maden, 1994; Wardhana, 1995; Denny, dkk, 1998 )

Struktur komunitas dari suatu lingkungan terutam lingkungan perairan adalah sensitive dan dapat dideterminasi oleh keadaan-keadaan atau faktor-faktor dan sumber-sumber yang tersedia dalam suatu habitat. Keadaan atau faktor tersebut mencakup faktor abiotik dengan rentangan waktu dan tempat seperti suhu, kadar garam, dan laju aliran. Organismes yang menempati komunitas di perairan adalah mereka yang toleran, punya ketahanan, dan mampu bereproduksi dalam habitat setempat. Jika habitat tersebut masih dalam lingkup toleransi yang dapat diterima, maka spesies tersebut berpotensi untuk hidup dalam lingkungan atau habitat tersebut (Begon, dkk, 1990, Newman, dkk, 1992). 
Setiap spesies mempunyai niche sendiri-sendiri, sehingga setiap dimensi dari hipervolume untuk semua faktor ekologi berkecenderungan dengan kemampuan spesies untuk hidup dan memperbanyak diri atau reproduksi. Niche adalah suatu ruang atau supervolume dalam struktur respon yang didalamnya terdapat kehidupan optimal yang dilingkupi oleh areal yang kurang menunjang untuk kehidupan yang optimal. Stress dapat merusak karakteristik lingkungan dari ekosistem perairan yang akan memberikan efek terhadap kehidupan organisme dalam ekosistem tersebut (Loeb dan Spacie, 1994). Dalam ekosistem perairan, perbedaan niche dari spesies yang spesifik yang hidup di dalamnya memberikan indikasi tentang tingkatan kondisi dan kualitas air.

Banyak spesies organisma secara biologi sudah digunakan oleh banyak peneliti untuk mendeterminasi perubahan sepanjang waktu seperti juga yang masih digunakan sampai saat sekarang. Keperluan untuk menentukan monitor secara biologi untuk air semakin meningkat. Hal ini dapat terjadi karena sejumkah besar bahan kimia mamasuki air dan tanah, dimana efeknya kadang-kadang sulit untuk dimengerti serta juga efeknya terhadap manusia masih belum jelas diketahui.
Organisme yang ada di air sangat berbeda sensitivitasnya terhadap berbagai bahan kimia, juga berbeda kebutuhan bahan kimia untuk kegiatan pertumbuhannya. Metode yang efektif adalah mempelajari semua organisma di dalam rantai makanan yang hidup dalam suatu area. Bukti dari kegiatan tersebut dapat dijadikan bahan untuk penarikan suatu kesimpulan. Perubahan besar dari sejumlah organisma dari suatu kelompok lain mengindikasikan telah terjadi perubahan sebelum mereka menjadi menderita. Jika salah satu tidak dapat dimonitor dari semua organisme dalam suatu ekosistem, maka bioindikator organisme di dalam air, adalah merupakan hal penting untuk memeperhatikan organisme yang penting dalam siklus materi dan aliran energi melalui jaring makanan.

Kegiatan memonitor secara biologi dapat digunakan dalam kejadian pertumpahan minyak, seperti tumpahan minyak dari kegiatan perkapalan/ sampah untuk pariwisata. Sangat penting memilih organisme yang secara terus menerus mengakumulasi sepanjang waktu. Juga penting untuk mengetahui waktu dari penampakan tentang kejadian akumulasi, sehingga penempatan alat untuk memonitor harus tepat dalam ekosistem yang menjadi sasaran untuk dimonitor. Beberapa 
organisme seperti kerang yang telah digunakan oleh EPA (Environmental Protection Agency), yang mana itu sangat bermanfaat sepanjang waktu akumulasi terjadi ( Jeffrey dan Maden, 1994).

Kelompok organisme yang terseleksi untuk menjadi monitor biologi (biomonitor) harus meluas distribusinya sehingga pengukuran terhadap suatu badan air dapat dibandingkan dengan badan air lainnya. Setiap spesies harus mempunyai syarat fisiologis dan mempunyai kesamaan dengan kelompok yang dominan dari kelompok spesies yang berbeda. Sebagai contoh penggunaan diatom sebagai indikator biologi, maka sebaiknya diatom juga sebagai indikator di perairan air lainnya. Adalah tidak bijak untuk menggunakan oligochaeta sebagai biomonitor pada suatu badan air, larva capung untuk badan air lain dan diatom untuk badan air yang ketiga, kalau ingin membandingkan kualitas air di ketiga badan air tersebut. (Loeb dan Spacie, 1994).

Rancangan untuk system monitor secara biologi adalah sangat penting. Syarat yang harus dipenuhi yaitu; pertama kolektor I pencacah harus mengumpulkan organisme yang hidup dalam air yang ingin diuji kualitasnya. Syarat kedua, pencacah harus memilih spesies yang penting dari transfer / pemindahan nutiren dalam jaring makanan.
Ketiga organisme tersebut harus aktif sepanjang tahun. Spesies sebagai indikator biologi (bioindikator) yang dipilih harus memenuhi kriteria seperti: spesies yang terpengaruh oleh perubahan lingkungan dalam badan air, spesies yang sensitive terhadap penyebab perubahan dalam badan ais, Spesies yang mudah menderita / terpengaruh kalau terjadi kerusakan lingkungan, spesies yang tetap punya karakter yang khusus dari sejumlah besar spesies lain dalam komunitasnya, kelimpahan harus memungkinkan untuk dikumpulkan walaupun dengan ukuran sampel yang besar dan spesies yang keberadaan tingkah lakunya mudah untuk diukur.

\section{BAHAN DAN METODE}

Penentuan satasiun ditentukan berdasarkan pertimbangan topograsi, yang dibagi menjadi 3 stasiun mewakili daerah hulu, daerah tengah dan daerah hilir. Pemilihan stasiun bisa dilakukan di sekitar Cakranegara, dan wilayah kecamatan Mataram. Data diambil dengan menggunakan jaring makroinvertebrata. Jaring diletakkan didasar perairan, selanjutnya dengan teknik kick method (hentakan kaki) selama 3 - 5 menit pada satu stasiun, maka akan diperoleh spesies makroinvertebrata. Pengambilan data 
diulangi sebanyak 3 kali untuk masing masing stasiun Makroinvrtebrata yang didapat akan diidentifikasi, dihitung dan dimasukkan dalam beberapa kategori sesuai dengan panduan perhitungan indek Lincoln. Spesies-spesies makro-invertebrata yang diperoleh aakan dihitung skor BMWP (Biological Monitoring working Party) dan
ASPT (Average score per Taxa) (Hootman, dkk, 1998, Mason, 1991). Tabel skor BMWP dan ASPT dan tingkatan nilai (rating) dapat dilihat seperti tabel 1 .

Tabel 1. Skor BMWP dan ASPT dan tingkatan nilai (rating)

\begin{tabular}{|c|c|c|c|c|}
\hline No. & Skor BMWP & Rating X & Skor ASPT & Rating Y \\
\hline 1. & $121+$ & 7 & $5+$ & 7 \\
\hline 2. & $101-120$ & 6 & $4,5-4,9$ & 6 \\
\hline 3. & $81-100$ & 5 & $4,1-4,4$ & 5 \\
\hline 4. & $51-80$ & 4 & $3,6-4$ & 4 \\
\hline 5. & $25-50$ & 3 & $3,1-3,5$ & 3 \\
\hline 6. & $10-24$ & 2 & $2,1-3,0$ & 2 \\
\hline 7. & $0-9$ & 1 & $0-2,0$ & 1 \\
\hline
\end{tabular}

Sumber : Mason, 1991.

Selanjutnya tingkatan nilai (rating $\mathrm{X}$ dan rating $Y$ ) digunakan untuk menghitung nilai OQR (Overall quality rating) dengan menggunakan formula sebagai berikut :
$\mathrm{OQR}=\mathrm{X}+\mathrm{Y} /$ 2. Nilai $\mathrm{OQR}$ adalah ekivalen dengan nilai indeks Loncoln. Nilai indeks Lincoln dan interpretasi kualitas lingkungan adalah seperti pada table 2 .

Tabel 2. Nilai indeks Lincoln dan interpretasi kualitas lingkungan

\begin{tabular}{|l|l|l|}
\hline Nilai OQR & Indeks (Lincoln) & Interpreasi kualitas lingkungan \\
\hline $6+$ & A ++ & Sangat sangat Baik \\
\hline 5,5 & A & Sangat sangat baik \\
\hline 5 & A & Sangat sangat baik \\
\hline 4,5 & B & Kualitas baik \\
\hline 4 & C & Kualitas baik \\
\hline 3,5 & D & Kualitas sedang \\
\hline 3 & E & Kualitas sedang \\
\hline 2,5 & F & Kualitas rendah \\
\hline 2 & G & Kualitas rendah \\
\hline 1,5 & H & Kualitas sangat rendah \\
\hline 1 & I & Kualitas sangat rendah \\
\hline
\end{tabular}

Sumber : Mason, 1991. 


\section{HASIL DAN PEMBAHASAN}

Hasil penelitian yang dilakukan di di kali Ancar pada satasiun 1 diperoleh data (Tabel1). Tingkatan nilai (rating $\mathrm{X}$ dan rating $\mathrm{Y}$ ) digunakan untuk menghitung nilai OQR (Overall quality rating). Penghitungan nilai OQR menggunakan formula sebagai berikut $: \mathrm{OQR}=\mathrm{X}+\mathrm{Y} / 2$. Data $\mathrm{OQR}$ untuk stasiun 1, 2 dan 3 berturut-turut adalah 2,5; 2,5 dan 2. Dari data yang diperoleh pada stasiun 1 (dibawah jembatan Unram), stasiun 2 ( dibawah jembatan jalan Airlangga) dan stasiun 3 (sekitar Cakranegara) dapat dengan mudah ditemukan bahwa skor Biological monitoring working party (BMWP) untuk stasiun 1, 2 dan 3 masing sebesar 24, 35 dan 12. Sementara untuk skor Average scor per taxa (ASPT) untuk stasiun 1, 2 dan 3 masing-masing sebesar 3; 3,5 dan 3 .

Tabel 3. Data perolehan pada stasiun 1.

\begin{tabular}{|l|l|c|c|c|}
\hline Taxa Makroinvertebrata & \multirow{2}{*}{ Skor } & \multicolumn{3}{|c|}{ Sampel } \\
\cline { 3 - 5 } & & 1 & 2 & 3 \\
\hline Hoglice & 3 & & & $\sqrt{ }$ \\
\hline Beetle Larvae & 5 & & & $\sqrt{ }$ \\
\hline Blackflies & 5 & & $\sqrt{ }$ & $\sqrt{ }$ \\
\hline Midges & 2 & & $\sqrt{ }$ \\
\hline Worms & 1 & $\sqrt{ }$ & $\sqrt{ }$ \\
\hline Hirudidae & 3 & $\sqrt{ }$ & \\
\hline Hydrobiidae & 3 & & & \\
\hline Valvatidae & 3 & & & \\
\hline & & & & \\
\hline Total BMWP score (a) & 24 & & & \\
\hline Total no of Taxa (b) & 8 & & & \\
\hline ASPT score (a/b) & 3 & & & \\
\hline Rating X (c) & 3 & & & \\
\hline Rating Y (d) & 2 & & & \\
\hline OQR (c + d)/ 2 & 2,5 & & & \\
\hline
\end{tabular}

Hasil penelitian yang dilakukan di di kali Ancar pada stasiun 2 diperoleh data sebagai berikut :

Tabel 4. Data perolehan pada stasiun 2.

\begin{tabular}{|l|l|c|c|c|}
\hline Taxa Makroinvertebrata & \multirow{2}{*}{ Skor } & \multicolumn{3}{|c|}{ Sampel } \\
\cline { 3 - 5 } & & 1 & 2 & 3 \\
\hline Hoglice & 3 & & $\sqrt{ }$ & $\sqrt{ }$ \\
\hline Worms & 1 & $\sqrt{ }$ & $\sqrt{ }$ & \\
\hline Planariidae & 5 & & & \\
\hline
\end{tabular}




\begin{tabular}{|l|l|l|l|l|}
\hline Hirudidae & 3 & & $\sqrt{ }$ & \\
\hline Hydrobiidae & 3 & $\sqrt{ }$ & $\sqrt{ }$ & $\sqrt{ }$ \\
\hline Limnaeidae & 3 & & $\sqrt{ }$ & $\sqrt{ }$ \\
\hline Neritidae & 6 & $\sqrt{ }$ & $\sqrt{ }$ \\
\hline Physidae & 3 & & & $\sqrt{ }$ \\
\hline Valvatidae & 3 & $\sqrt{ }$ & \\
\hline Viviparidae & 6 & & $\sqrt{ }$ & \\
\hline & & & & \\
Total BMWP score (a) & 35 & & & \\
\hline Total no of Taxa (b) & 10 & & & \\
\hline ASPT score (a/b) & 3,5 & & & \\
\hline Rating X (c) & 3 & & & \\
\hline Rating Y (d) & 2 & & & \\
\hline OQR (c + d)/2 & 2,5 & & & \\
\hline
\end{tabular}

Sementara pada stasiun 3 diperoleh data seperti berikut

Tabel 5. Data perolehan pada stasiun 3.

\begin{tabular}{|l|l|l|c|c|}
\hline Taxa Makroinvertebrata & \multirow{2}{*}{ Skor } & \multicolumn{3}{|c|}{ Sampel } \\
\cline { 3 - 5 } & & 1 & 2 & 3 \\
\hline Beetle Larvae & 5 & $\sqrt{ }$ & $\sqrt{ }$ & \\
\hline Worms & 1 & $\sqrt{ }$ & $\sqrt{ }$ & $\sqrt{ }$ \\
\hline Hirudidae & 3 & $\sqrt{ }$ & & $\sqrt{ }$ \\
\hline Hydrobiidae & 3 & & & \\
\hline & & & & \\
Total BMWP score (a) & 12 & & & \\
\hline Total no of Taxa (b) & 4 & & & \\
\hline ASPT score (a/b) & 3 & & & \\
\hline Rating X (c) & 2 & & & \\
\hline Rating Y (d) & 2 & & & \\
\hline OQR (c + d)/2 & 2 & & & \\
\hline
\end{tabular}

Data hasil olahan data yang dapat digunakan untuk menentukan kualitas air di kali Ancar adalah skor Overall quality reting (OQR) yang didapat pada stasiun 1,2, dan 3 yang masing masing seberar 2,$5 ; 2,5$ dan 2 . Skor 2 dan 2,5 dapat dikonsultasikan dengan tabel 2, yang menunjukkan bahwa kualitas air adalah masuk kategori kualitas rendah.
Kategori rendah pada air sungai Ancar akan mudah dipahami oleh pakar lingkungan, karena pada sungai tersebut ditemukan banyak sekali jenis sampah dan buangan limbah cai sepanjang sungai tersebut. Tekanan terhadap air sungai ancar akan semakin berat ketika program kali bersih tidak berjalan dengan baik, demikian juga dengan monitoring yang bisa dilakukan 
oleh instansi yang bertanggung jawab terhadap keberadaan sungai tidak berlangsung dengan rutin setiap bulan atau setiap triwulan sekali. Ini didukung oleh penelitian Chaerul, dkk, (2007) yang mengatakan bahwa pengelolaan sampah di Indonesia kurang baik. Selain itu hasil penelitian Kusnandi (2015) menunjukkan bahwa kali Ancar telah mengalami pencemaran.

Menurut Wardhana (2001) komponen pencemaran air dapat dikelompokkan sebagai bahan buangan 1) Padat 2) Organik 3) Anorganik 4) Olahan bahan makanan 5). Cairan berminyak 6). Zat kimia dan 7) Berupa panas. Air yang ada di sungai Ancar menerima hampir semuua jenis bahan buangan ini baik berupa zat padat, organik, anorganik, cairan berminyak dan lain-lainnya.Hal ini dapat dengan mudah diamati di sepanjang sungai atau kali ancar. Banyak sampah yang diperoleh pada sata pengambilan sampel baik pada stasiun 2, stasiun 3 maupun pada stasiun 3.

Dari tabel 3, 4,dan 5, dapat dengan mudah dipahami bahwa spesies dalam taxa tersebut menunjukan bahwa spsesies-spesies ini adalah spesies yang toleran terhadap adanya pencemaran terutama pencemaran dari bahan organik. Cacing merah adalah spesies yang sangat toleran terhadap adanya pencemaran dalam perairan sungai. Makin banyak ditemukan cacing merah akan menujukkan bahwa makin tercemar kualitas air sungai tersebut. Spesies cacing merah adalah spesies yang dapat hidup dan berkembang pada kisaran toleransi yang sangat luas, artinya kelompok ini sering di jumpai di perairan yang tercemar atau berkualitas buruk dimana umumnya kelompok ini peka terhadap berbagai bentuk dan tekanan serta kelimpahanya terus bertambah di perairan yang tercemar bahan organik. Jenis yang bersifat toleran di sungai Ancar yakni dari spesies cacing merah dimana jenis ini yang paling sering di temukan di setiap stasiun yaitu stasiun 1, 2 dan 3, hal ini dikarenakan sungai Ancar substratnya berpasir dan berlumpur sehingga kebanyakan yang di temukan adalah jenis cacing yang dominan hidup di substrat berlumpur dan mempunyai tipe cara makan deposit feeder. Kabiasaan Cacing merah secara umum adalah ujung membenamkan ujung anteriornya di dasar perairan seperti lumpur, berwarna merah, pink, kadang terbungkus suatu selubung yang ujung posteriornya dilambaikan untuk memperoleh oksigen sehingga tahan pada kandungan oksigen yang rendah serta mempunyai tingkat toleran yang tinggi terhadap 
pencemaran terutama kandungan bahan organik yang tinggi hal ini menggambarkan bahwa adanya pencemaran bahan organik di sungai atau kali Ancar.

Dari tabel 3 dan 5 ditemukan adanya spesies dari taxa Beetle larvae yang secara umum berada pada air yang berkualitas bersih dan atau berkualitas sedang. Demikian juga pada tabel 4 ditemukan adanya spesies dari taxa Neritidae yang umumnya berada pada air yang berkualitas bersih, dan atau pada air sungai yang berkualitas sedang. Ini menujukkan bahwa air sungai Ancar masih mungkin untuk ditingkatkan kualitasnya dengan cara mengelola bahan buangan padat, cair, organik, anorganik, air panas yang dibung ke kali ancar.

\section{Kesimpulan}

Dari hasil penelitian dan pembahasan dapat disimpulkan bahwa tingkat kualitas air di kali Ancar Mataram tergolong kualitas rendah. Perlu ada penelitian yang rutin sepanjang tahun unutk mendapat data yang berseri setiap periode waktu sepanjang tahun di kali Ancar, sehingga perubahan kualitas air dapat diketahui setiap saat.

\section{DAFTAR PUSTAKA}

Anonim, 2000. Undang-undang Republik Indonesia Nomor 23 Tahun 1997 Tentang Pengelolaan Lingkungan hidup. Himpunan Peraturan Tentang Pengendalian Dampak Lingkungan. Bapedalda NTB. Mataram

Bakrie, M. 2000. Penyisihan Timbal (Pb) dari air buangan dengan sementasi menggunakan bola-bola besi. Manusia dan Lingkungan (jurnal, Volume VIII No.2 Tahun 2000). Jakarta.

Begon, M; Harper, J.L; dan Toensend, C.R. 1990. Ecology. Blackwell Science Ltd. Oxford.

Chaerul, M, ; Tanaka, M, ; dan Shrkdar, AV. 2007. Journal of Tht Faculty of Environmenttal science and Technology. Okayama University. Vol. 12. No. 1, pp 41 - 49. Japan

Denny, P; Savenije, H.H.G dan Van Bruggen, J.J.A, 1998. Environmental Quality.

Golterman, H.L, 1998. Aquatic Ecosystems. IHE Delft. The Netherlands.

Hootmans, M; Minns, T; De Ruyter van Stevenink, E.D dan Vermaat, J. 1998. Fieldwork Limburgh, A Chemical, Biological and 
Hydrological Study. IHE Delft. The Netherlands.

Jeffrey, D.W; dan Maden, B, 1994. Bioindicator and Environmental Management. Academic Press Limited. London.

Loeb, S.L. dan Spacie, A. 1994. Biological Monitoring of Aquatuic System. Lewis Publishers. Florida, United States of America.

Kusnandi, A. 2015. Annelida Sebagai Bioindikator Pencemaran Sungai Ancar Kota Mataram Dan Upaya

Pembuatan Poster Untuk

Pendidikan Masyarakat Tahun

2013. Prosiding Seminar Nasional

Pendidikan Biologi 2015. Prodi

Pendidikan Biologi FKIP

Universitas Muhammadiyah

Malang. Malang

Mason, C.F. 1991. Biology of Freshwater Pollution. Longman Group. United Kingdom.

Newman, P.J.; Piavaux, M.A dan Seeting, R.A. 1992. River Water Quality Ecological Assessment and Control. Commision of The European Communities. Brussels, Belgium.

Sanu, P. 2001. Melindungi Lingkungan, Gramedia, Jakarta
Schippers, J.C. 1998. Water Treatment. IHE Delft. The Netherlands.

Soedradjad, R, 1999. Lingkungan Hidup. Ditjen Dikti, Dekdikbud, Jakarta.

Soemantojo. 2004. Pendidikan dan Etika Lingkungan Hidup, Jurnal Lingkungan dan Pembangunan Volume 24 Nomor $1: 23$.

Tanjung, S.D. 2003. Ilmu Lingkungan. Laboratorium Ekologi, Fakultas Biologi, Universitas Gadjah Mada. Yogjakarta.

Wardhana, W.A, $1995 . \quad$ Dampak Pencemaran Lingkungan. Andi Offset, Jakarta.

Wardhana, W.A, 2001. Dampak Pencemaran Lingkungan. Andi, Yogjakarta.

Hadi, S.P, 2000. Manusia dan Lingkungan. Badan Penerbit Universitas Diponegoro, Semarang.

http://sumbawabaratnews.com, 2014).

Badan Lingkungan Hidup dan Penelitian NTB. Kualitas Air Sungai Mataram Makin Parah, diakses 12 Maret 2014

http://hanifweb.wordpress.com/2013/04/19/ pencemaran-air/. Pencemaran Air. diakses 9-3-2014

Maryono, 2007. Restorasi Sungai. Gadjah Mada University Presss. Yogjakarta. 
Sukarsono, 2009. Ekologi Hewan. UMM

Press, Malang.

Widowati, W; Sastiono, A; dan Yusuf, R.

2008. Efek Toksik Logam. Andi, Yogjakarta. 